IIIIIIIIIIIIIIIIIIIIIIIIIIIII

解

説

|IIIIIIIIIIIIIIIIIIIIIIIIIII

\title{
100 グラムスケールの製造供給を可能にした農業「鍵」天然物
}

\author{
菅 敏幸 ${ }^{1, *}$, 稲井 誠 ${ }^{1}$, 大内仁志 ${ }^{1}$, 浅川倫 宏 ${ }^{2}$

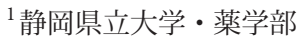 \\ ${ }^{2}$ 東海大学・創造科学技術研究機構
}

（2019年5月27日受理）

\section{Demonstration of practical synthesis of agriculture key compounds enable $100 \mathrm{~g}$ scaling}

\author{
Toshiyuki Kan, ${ }^{1}$ Makoto InaI, ${ }^{1}$ Hitoshi Ouchi ${ }^{1}$ and Tomohiro Asakawa ${ }^{2}$ \\ ${ }^{1}$ School of Pharmaceutical Sciences, University of Shizuoka, 52-1 Yada, Suruga-ku, Shizuoka 422-8526, Japan \\ ${ }^{2}$ Tokai University Institute of Innovative Science and Technology, 4-1-1 Kitakaname, Hiratsuka-city, Kanagawa 259-1292, Japan
}

Keywords: Practical total syntheses, natural products, nobiletin, citrus fruits, fairy chemicals, agrochemicals.

\section{は じめに}

筆者は，学生時代より魅力溢れる天然物の全合成をテーマ として研究を続ける幸運に恵まれてきた。しかし，昔から 「意味があるの?」とか「既知反応の組み合わせじゃない?」 という類の発言を耳にするたびに,「いつかは世の中の役に 立つ全合成をしたい」と夢みてきた。また，2005年に静岡 にて独立して研究テーマを選定できる自由を得たが，相変わ らず「頼まれる天然物」の合成に追われている。しかし，静 岡に赴任してからは薬学に所属するにも関わらず農業に関係 する化合物の合成が多くなっている，幸いにも共同研究者た ちに頼まれた天然物のノビレチン（1）やフェアリー化合物 $(2,3,4)$ の 100 グラムスケールでの合成に成功して, 少しだ け農業のお役に立つことができたので紹介する.

\section{1. ノビレチンの合成}

\section{1. 眠れる天然物ノビレチン}

柑橘類に多く含まれるノビレチン（1）は，1938年に単離

日本農薬学会第 44 回大会特別講演の内容

* = 422-8526 静岡県静岡市駿河区谷田 52-1 静岡県立大学薬学部

E-mail: kant@u-shizuoka-ken.ac.jp

(C) 日本農薬学会

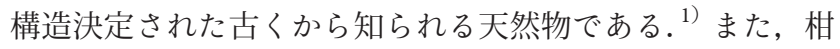
橘の果皮を乾燥させた「陳皮」は漢方薬の成分として知られ 調味料としても用いられてきた。しかし，ノビレチン（1） には顕著な生物活性の報告もなく注目を集めることが少な かった.しかし，21世紀に入り新規疾患のアッセイ法が出 現して，ノビレチンがそれらに有効であることが報告され， 俄然注目を集めている。例えば，2000年に京都大学の大東 先生は新規抗がん作用 ${ }^{2)}$ を, 2007 年に東北大学の大泉先生 は認知症予防 ${ }^{3)}$ に有効であることを報告した。さらに，「温 州みかん」は静岡の特産品のため, 薬食研究を掲げる本学で は多くの研究者が興味を持っていた。 そこで, 静岡に赴任 直後の筆者（TK）は効率的合成による実用的供給が静岡コ ミュニティーへの仲間入りを実現すると，甘い考えを持ち合 成研究に着手した。

\section{2. ノビレチンのプロセス合成}

筆者 (TK) が赴任当初, 静岡県立大学では文部科学省の 21 世紀拉よびグローバル COE 事業に採択され薬学部と食品 栄養科学部が共同研究として薬食融合研究を推進していた。 その一環として, 後に当研究室の講師となる脇本博士（現： 北大薬学部教授) は, ウーロン茶から強力な抗炎症作用を有 する配糖体フラボノイドのチャフロサイドの単離構造決定に 成功した. 当研究室では, そのユニークな構造と生物活性に 
<smiles>COc1ccc(-c2cc(=O)c3c(OC)c(OC)c(OC)c(OC)c3o2)cc1OC</smiles>

Nobiletin (1)<smiles>NC(=O)c1c[nH]cn1</smiles>

$\operatorname{ICA}(2)$<smiles>O=c1[nH]nnc2[nH]cnc12</smiles>

$\mathrm{AHX}(3)$<smiles>O=c1[nH]c2nn[nH]c(=O)c2[nH]1</smiles>

$\mathrm{AOH}(4)$

Fairy chemicals (FCs: 2, 3, 4)

図1.100グラムスケールでの合成に成功した天然物.

興味を持ち合成研究を開始した。その合成の際に，新規かつ 効率的な新規フラボン環構築法の開発にも成功し, チャフロ サイドの全合成が可能となった. ${ }^{4)}$ そこで，本フラボン環構 築法を基盤とすることでノビレチン（1）の効率的な合成も 可能になると考えた，その合成戦略をスキーム 1 に示した. われわれの知見を基にすると，ノビレチンはアセトフェノン 6 とアシルドナー 7のカップリングにより得られる $\beta$-ジケト ン 5 に対する酸性条件での環化と脱水により容易に合成可能 である。そのため，ポリメトキアセトフェノン6をいかに効 率的に合成するかが，ノビレチン（1）の合成の鍵になると 考えた。

当初は文献既知の方法に従い，スキーム 2 に示したルート にて6の合成を検討した。まず, 1,2,3,5-テトラメトキシベン ゼン（8）に対し塩化アセチルと $\mathrm{AlCl}_{3}$ により Friedel-Crafts 反応を行いアセチル基の導入を行った，本反応では脱メチ ル化体も副生したが，精製の必要もなくメチルエーテル化 反応により9を得た。続いて， $m$ CPBAによるアセチル基の Baeyer-Villiger反応と塩基性条件での加溶媒分解を行いフェ ノール11が得られた．続く，フェノール11に対する同様の 反応により6の合成は可能であったが，このメトキシ基導入 工程はスケールアップに多くの問題があった。まず，テト ラメトキシフェノール11 は, 酸素に不安定なため単離精製 には脱気条件も必要とされた，また，副生する $m$ CBA（12） と 11 の分離は容易ではなく, 煩雑なシリカゲルカラムクロ マトによる精製が必要であった。これらの問題を解決するプ ロセス合成には新規のルートの開発が必須となった。しか し，本合成を通して電子豊富な芳香環への酸素官能基の導入 には, 求電子置換反応と Baeyer-Villiger型反応の組み合わせ が非常に有効であることを経験した。 そのため, 本合成戦
略を基盤としたスキーム3に示す改良ルートを開発すること で, プロセス合成が可能となった。

合成は，安価な $1,2,3$-トリメトキシベンゼン（14）を出発 原料とした。 スキーム3に示したように, 14 に $\mathrm{CH}_{3} \mathrm{OCHCl}_{2}$ と $\mathrm{TiCl}_{4}$ を作用させると求電子置換反応が円滑に進行し, 心゙ ンズアルデヒド15が単一化合物として得られた。また，14 には4位と5位の2箇所の反応点があるが，オルト位とパラ 位の二つのメトキシ基にて活性化される4位選択的に反応は 進行し単一化合物として得られた。さらに, 得られた 15 に 触媒量の $\mathrm{SeO}_{2}$ 存在下 $\mathrm{H}_{2} \mathrm{O}_{2}$ を作用させると Baeyer-Villiger 型の反応が円滑に進行してホルミルエステル17が得られた. 本反応は, 中間体 16 を経由する転位反応として進行するた め, 反応にて副生するのは $\mathrm{H}_{2} \mathrm{O}$ のみである。 そのため, シ リカゲルクロマトグラフィーのような煩雑な精製操作が不 要となった. さらに, 17 の加水分解とメチル化によりテト ラメトキシベンゼン19を得た．続いて，19へのホルミル基 の導入は改良型の Vilsmeier反応により円滑に可能となった. 汎用されるDMFによるVilsmeier反応では高温が必要とさ れたが，メチル基をフェニル基へと変更した改良型反応では 活性中間体か室温にて発生可能となった。続く, フェノール への変換は 15 の時と同様に触媒量の $\mathrm{SeO}_{2}$ と $\mathrm{H}_{2} \mathrm{O}_{2}$ により酸 化後, エステルの分解を経て 21 を得た. 21 をメチル化後, 次いで塩化アセチルと $\mathrm{AlCl}_{3}$ による Friedel-Crafts反応を行 うことで，アセトフェノン誘導体6を合成した，本反応で は，アセチル基に配位した $\mathrm{Al}$ 原子が隣接するメチルエーテ ルの酸素原子を活性化して, 塩素原子により脱メチル化反応 が進行したと考えている.しかし, 続くClaisen型の縮合反 応はフェノール共存下においても進行するため, 本副反応は 好都合となった。<smiles>COc1ccc(C(=O)CC(=O)c2c(O)c(OC)c(OC)c(OC)c2OC)cc1OC</smiles>

スキーム 1. ノビレチンの合成戦略. 


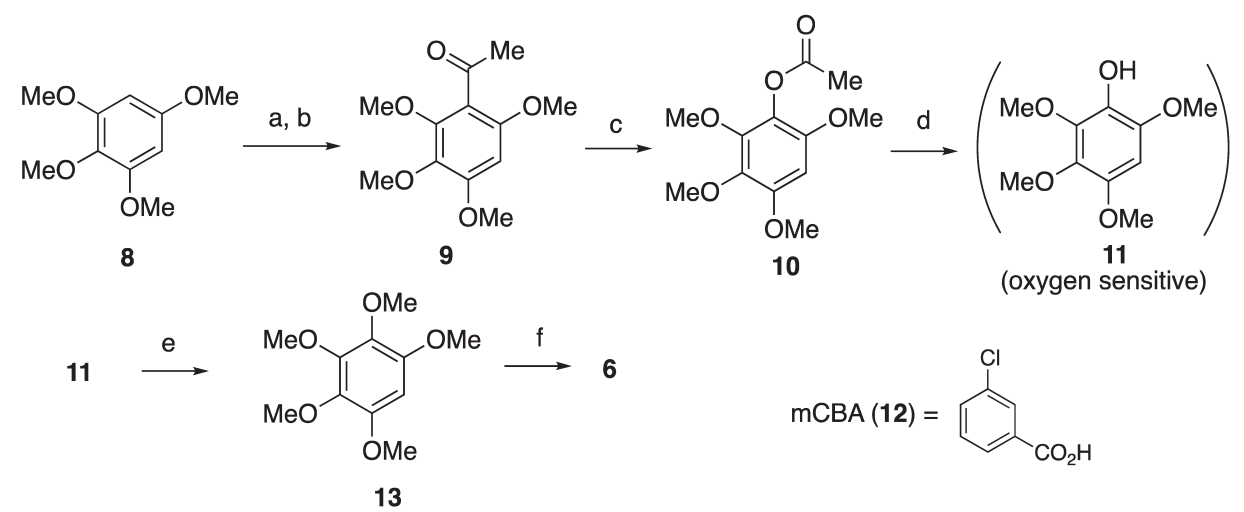

Conditions: (a) $\mathrm{AcCl}, \mathrm{AlCl}_{3}, \mathrm{Et}_{2} \mathrm{O}, 76 \%$; (b) $\mathrm{Mel}, \mathrm{K}_{2} \mathrm{CO}_{3}, \mathrm{DMF}, 70{ }^{\circ} \mathrm{C}, 94 \%$; (c) $m \mathrm{CPBA}$, $\mathrm{CH}_{2} \mathrm{Cl}_{2}$ then $\mathrm{SiO}_{2}$ C.C.; (d) $\mathrm{K}_{2} \mathrm{CO}_{3} \mathrm{MeOH}$ then $\mathrm{SiO}_{2}$ C.C. under air; (e) Mel, $\mathrm{K}_{2} \mathrm{CO}_{3}$, acetone, 95\% (f) $\mathrm{AcCl}, \mathrm{AlCl}_{3}, \mathrm{CH}_{2} \mathrm{Cl}_{2}, 45 \%$ (brsm 94\%).

$$
\text { スキーム 2. 文献既知のアセトフェノン } 6 \text { の合成ルート. }
$$

スキーム4に，6からノビレチンへの合成ルートを示した. 我々の開発したフラボン合成法に従い安息香酸誘導体 22 を 酸塩化物 23 経由にてアシルベンゾトリアゾール $7^{5)}$ ヘと変換 した. 続く, アセトフェノン誘導体 6 と 7 とのClaisen縮合 反応は lithium hexamethyldisilazide (LHMDS) 存在下円滑 に進行して $\beta$-ジケトン $\mathbf{5}$ が得られた。引き続き， $\mathrm{MeOH}$ 中 TFA 作用させると, 酸性条件での環化と脱水が円滑に進 行し1を得た. 本合成は 11 段階, 総収率 $53 \%$ で進行し, 極 低温条件や一切のクロマト精製も必要としなかった。 ${ }^{6)}$ その ため, プロセス合成が可能となり, ウシオケミックス社の御 前崎工場では 100 グラムスケールでの製造が実施された。ウ
シオケミックス社に，そのプロセスルートの開示をお願いし たところ，すべての工程の反応試薬は実験室で開発したルー トのものと全く同様であった。しかし, 細かい反応条件は最 適化されており, 特に最後のClaisen 縮合反応では- $30^{\circ} \mathrm{C}$ 中 4 当量のLHMDS と 1.09 当量の 7 を用いることで定量的に $\beta$ ジケトンを得ていた. また, 最後のノビレチンはTHFとへ プタンからの再結晶により高純度のノビレチンを得るなど, 高度な最適化によりプロセス合成が可能となっていることが 明らかとなった。

さらに, 合成品は和光純薬工業株式会社より試薬として も販売され，天然物の精製化合物が 2 万円／10 $\mathrm{mg}^{7 \mathrm{a})}$ に対し

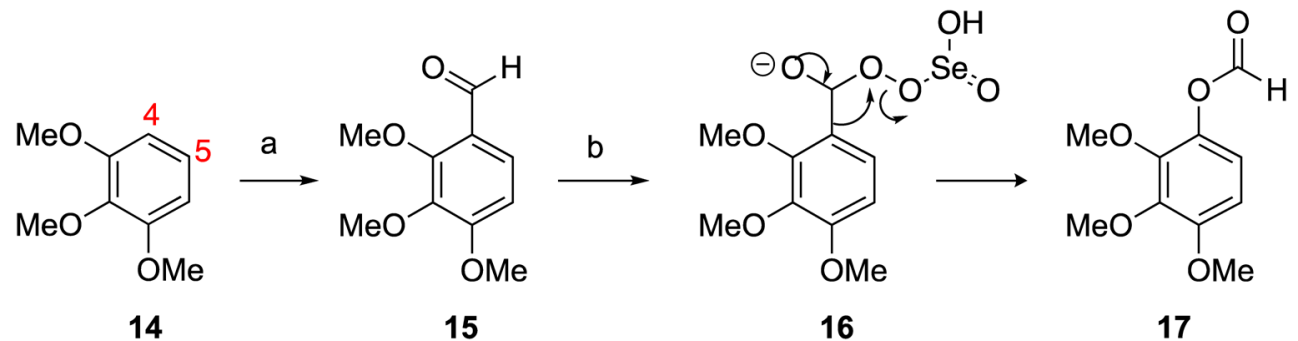<smiles>[R7]Oc1ccc(OC)c(OC)c1OC</smiles>

Conditions: (a) $\mathrm{TiCl}_{4}, \mathrm{Cl}_{2} \mathrm{CHOMe}, \mathrm{CH}_{2} \mathrm{Cl}_{2}$; (b) $\mathrm{SeO}_{2}$ (cat.), $30 \% \mathrm{H}_{2} \mathrm{O}_{2}, t-\mathrm{BuOH}, 50$ ${ }^{\circ} \mathrm{C}$; (c) $\mathrm{Et}_{3} \mathrm{~N}, \mathrm{MeOH}$; (d) $\mathrm{Mel}, \mathrm{K}_{2} \mathrm{CO}_{3}$, acetone, 84\% (4 steps); (e) $\mathrm{PhN}(\mathrm{Me}) \mathrm{CHO}$, $\mathrm{POCl}_{3}, 60^{\circ} \mathrm{C}$; (f) $\mathrm{SeO}_{2}$ (cat.), $30 \% \mathrm{H}_{2} \mathrm{O}_{2}, t-\mathrm{BuOH}, 50{ }^{\circ} \mathrm{C}$; (g) $\mathrm{Et}_{3} \mathrm{~N}, \mathrm{MeOH}$; (h) Mel, $\mathrm{K}_{2} \mathrm{CO}_{3}$, acetone, $94 \%$ (4 steps); (i) $\mathrm{AcCl}, \mathrm{AlCl}_{3}, \mathrm{CH}_{2} \mathrm{Cl}_{2}, 45 \%$ (brsm 94\%).

$$
\text { スキーム 3. アセトフェノン6のプロセス合成ルート. }
$$




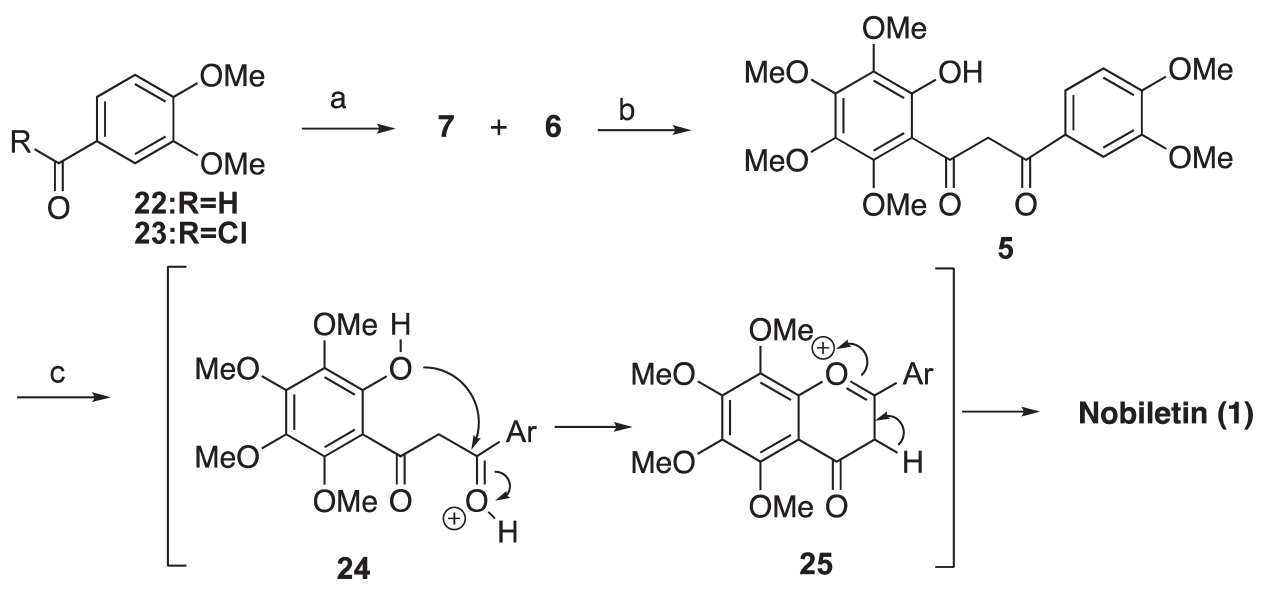

Conditions: (a) $\mathrm{SOCl}_{2}$, DMF, $\mathrm{CH}_{2} \mathrm{Cl}_{2}$ then benzotriazole; (b) LHMDS, THF, $0{ }^{\circ} \mathrm{C}, 91 \%$; (c) TFA, $\mathrm{MeOH}, 50^{\circ} \mathrm{C}, 98 \%$.

$$
\text { スキーム 4. アシルドナー } 7 \text { との縮合によるノビレチンの合成. }
$$

て合成品は 5 万円 $/ 500 \mathrm{mg}^{\mathrm{7b})}$ の $1 / 20$ となる価格破壊も実現 した.また, ウシオケミックス社のご厚意により, 本学の 17 を超えるノビレチン研究を実施するグループには 5 グラム （天然物換算, 二千万円）の無償配布をいただいた。この恩 恵により，微量かつ高価な天然由来のノビレチンでは不可能 であったノックアウトマウスでの動物実験も可能にした。

\section{3. スダチチン類（ノビレチンの推定代謝物）の合成} 調味料としても好まれる相橘類のスダチの果皮にもポリメ トキシフラボンのスダチチン（29）が存在することが知られ ている。また，ノビレチンの脱メチル誘導体の 29 にも，血 糖值降下作用などノビレチンと同様の医薬品として期待さ れる活性が報告されている. ${ }^{8)}$ 我々は, この脱メチ儿誘導体 とノビレチンとの構造と生物活性の相関関係に興味を持ち, 29の合成研究に着手した。また，スダチチン（29）は，1の カルボニル基と共役した酸性度の高いフェノールの脱メチル 誘導体であるため, 合成中間体の6の脱メチル化反応により 容易に合成可能と考えた。まず，アセトフェノン 6 に $\mathrm{LiCl}$ を 作用させると 7位選択的な脱メチル化反応が進行した. 本反 応では30のようにリチウムイオンがカルボニルに配位して
活性化することによりパラ位選択的な脱メチル化反応が進行 したと考えている.ささらに，生じた水酸基を $\mathrm{Bn}$ 基にて保護 した後, 26 とアシルベンゾトリアゾール 27 とのカップリン グ反応は円滑に進行し, 酸性条件での環化と脱水反応により フラボン 28 が得られた。この酸性条件の反応ではフェノー ルのベンジルエーテルの除去も進行した．続いて28のフェ ノールを電子求引性のアセチル基にて保護した後, EtSH存 在下 $\mathrm{AlCl}_{3}$ を作用させると 5 位選択的な脱メチル化反応が進 行した. 最後に, アンモニアを作用させることで穏和な条件 でアセチル基を除去しスダチチン（29）を合成した．また， これら 3 䇢所の簡便な脱メチル化反応を組み合わせることに より, 図 2 に示した 6 種のノビレチンの脱メチル体 30-35も 合成した。 スダチチンを含むこれら誘導体はカルボニルに共 役した酸性度の高いフェノールの脱メチル誘導体のため, , ビレチンの代謝物として考えている，すなわち，メチル基の 酵素的な酸化反応と加水分解反応により脱メチル化反応が進 行したものと考えている.

また, 完熟のものと比較すると未熟の相橘はノビレチンを 圧倒的に多く含有することが知られている。 さらに，相橘は 成熟とともに糖が増加することから，ノビレチンには脱メチ<smiles>[R20]c1ccc(-c2cc(=O)c3c(OC)c(OC)c([R20])c(OC)c3o2)cc1OC</smiles>

\begin{tabular}{rcccc} 
& $R^{1}$ & $R^{2}$ & $R^{3}$ \\
\hline 1 & $M e$ & $M e$ & $M e$ \\
29 & $H$ & $H$ & $H$ \\
30 & $M e$ & $H$ & $H$ \\
31 & $M e$ & $M e$ & $H$ \\
32 & $H$ & $M e$ & $H$ \\
33 & $H$ & $M e$ & $M e$ \\
34 & $M e$ & $H$ & $M e$ \\
35 & $H$ & $H$ & $M e$
\end{tabular}<smiles>COc1cc(-c2cc(=O)c3c(O)c(OC)c(O[C@@H]4O[C@H](CO)[C@@H](O)[C@H](O)C4O)c(OC)c3o2)ccc1O</smiles>

図2. 合成したノビレチン誘導体（推定代謝物）. 
<smiles>COc1cc(-c2cc(=O)c3c(OC)c(OC)c(O)c(OC)c3o2)ccc1OCC(C)(C)C</smiles><smiles>COc1cc(-c2cc(=O)c3c(O)c(OC)c(O)c(OC)c3o2)ccc1O</smiles><smiles>COc1c(OC)c(OC)c(C(=O)O)c(OC)c1OC</smiles>

Conditions: (a) LiCl, DMF, $120{ }^{\circ} \mathrm{C}, 59 \%$ (brsm 70\%); (b) $\mathrm{BnBr}, \mathrm{K}_{2} \mathrm{CO}_{3}, \mathrm{DMF}, 79 \%$; (c) LHMDS, THF, $-78{ }^{\circ} \mathrm{C}$ to $0^{\circ} \mathrm{C}, 87 \%$; (d) $\mathrm{TsOH}$, toluene, $80^{\circ} \mathrm{C}, 93 \%$; (e) Ac $\mathrm{Ac}_{2} \mathrm{O}$, DMAP, pyridine; (f) EtSH, $\mathrm{AlCl}_{3}, \mathrm{CH}_{2} \mathrm{Cl}_{2}, 0^{\circ} \mathrm{C}$ to rt, $67 \%$ (2 steps); (g) $\mathrm{NH}_{3}, \mathrm{MeOH}, 69 \%$

スキーム 5. スダチチンの合成ルート

ル化と,引き続いて起こる配糖化を経て 36 となり排出され る代謝経路が存在すると考えている，その仮説を基にする と，図2に示した推定代謝物や配糖体 36 は，ノビレチンが 代謝される前の高含量の柑橘の収穫時期の指標になると考え ている. 未発表データではあるが, 岡山理科大の濱田博喜教 授との共同研究にて生体触媒を用いた 36 の合成に成功して いる. さらに, 本学食品栄養科学部の三好規之准教授との共 同研究にて，ノビレチン，スダチチンと図 2 の推定代謝物の 8種の混合物のLC-MSによる簡便な分析方法が確立された。 これらの分析方法により, ノビレチン高含量の相桶の収穫を 可能にするため，栽培に対する貢献は絶大であると考えてい る.

\section{2. フェアリー化合物の合成}

\section{1. 妖精の輪の原因物質（フェアリー化合物）の発見}

公園やゴルフ場などで芝生が輪状に周囲より色濃く繁茂 し, 時には逆に輪状に成長が抑制され，後にその輪の上に キノコが発生する現象があり,「フェアリーリング（Fairy Rings, 妖精の輪)」と呼ばれている.これは, 西洋の伝説 では，妖精「フェアリー」が輪を作りその中で踊ると伝え られていることに由来する．1675年にフェアリーリングに 関する最初の科学的論文が発表され，その論文が 1884年の Nature（H. Evershed: Nature 29, 384 (1884)）に紹介されて 以来，その妖精の正体（芝を繁茂させる原因）は謎のままで あった．静岡大学の河岸洋和教授は, 自身の宿舎前の芝生に フェアリーリング現象を発見した際, 芝生の繁茂後に円状に コムラサキシメジが現れることを発見した．そのため，この キノコが原因物質を産生すると考え，コムラサキシメジの菌 糸体を培養して, その培養液から妖精の正体 ICA（2: imidazolecarboxamide) とAHX (3: azahypoxanthine) の単離・ 構造決定に成功した. ${ }^{9)} そ し て ， 3$ は芝に投与すると濃度依
存的に成長を促進することも明らかにした，さらに，3は植 物に投与すると $\mathrm{AOH}(4)$ に代謝されることを明らかにし， 3 よりも強い成長促進活性を有することも見出した. ${ }^{10)}$ また, 我々の報告を紹介した Nature誌（Mitchinson, 2014）がこれ ら植物成長化合物を「フェアリー化合物（FCs）」と名付け て紹介したことから，これを慣用名として使用している。さ らに, 静岡大学のグループは戋場実験にて, FCsが稲や小麦 の収量を大幅に増加させることも明らかとした．また，FCs 投与後の成長制御の分子機構を植物の遺伝子解析 (DNA 又 イクロアレイ, RT-PCRなど）により検討した結果，FCsは 植物に様々なストレス（高温, 低温, 塩, 乾燥など）への耐 性を与え, 結果的に成長を促すと結論づけた。このような FCs の特性により, 寒冷地だけでなく広大な砂漠でも作物の 栽培が可能になれば, 将来迎える世界の食料危機からの救済 や二酸化炭素削減などが大きく期待できる. そのため, 静 岡大学の藤枝戋場での試験（畑に撒く）を可能にする大量ス

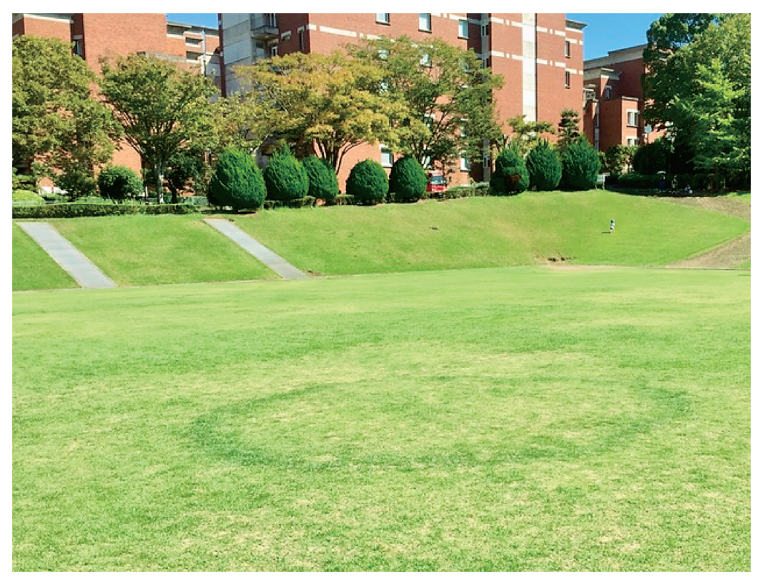

図3. 静岡県立大学に発生したフェアリーリング（2016年10月 6日） 


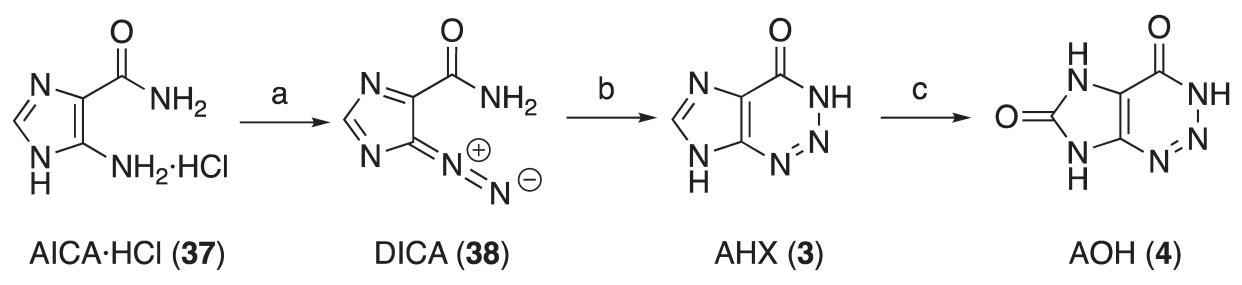

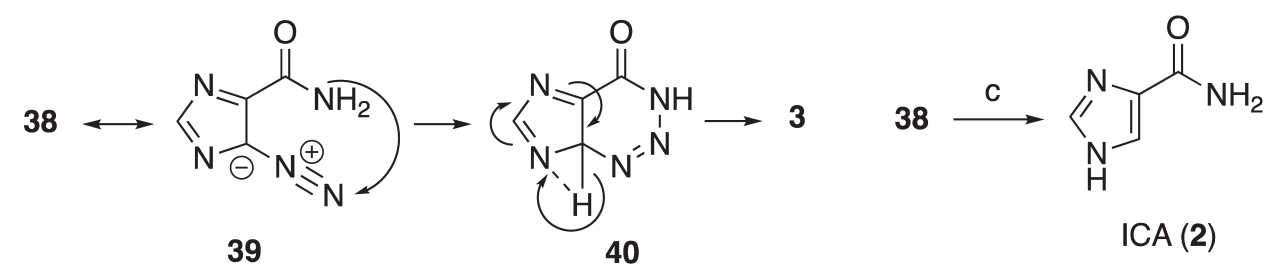

Conditions; (a) $\mathrm{NaNO}_{2}, 2 \mathrm{M} \mathrm{HCl}, 80 \%$ (b) $\mathrm{MeOH}, 60{ }^{\circ} \mathrm{C}, 75 \%$ (c) $\mathrm{H}_{2}, \mathrm{Rh} / \mathrm{C}, \mathrm{MeOH}, 63 \%$ (d) Microorganism (Burkholderia contaminans), 99\%

スキーム6. フェアリー化合物（FCs）の実用的合成ルート.

ケール（100グラム以上）での合成を検討した。

\section{2. フェアリー化合物（FCs）のプロセス合成}

フェアリー化合物（FCs）の 2 と 3 の合成は文献既知で あったが，当研究室では工程の見直しを行いプロセス合成が 可能な方法に改良した。その結果，ウシオケミックス社の御 前崎工場では，スキーム 5 に示したルートにて 100 グラムス ケールでの生産を実現できた。

スキーム5に示したように，安価なAICA塩酸塩（37: aminoimidazole carboxamide）に塩酸酸性条件下にて亜硝 酸ナトリウムを加えることでジアゾ化反応が進行し, DICA (38: diazoimidazolecarboxamide) が得られた。文献では, 反応終了後に固体として得られる 38 をンモニア水と処理 して AHX（3）へと変換していた.しかし，本反応は38の 互変異性体 39 に対する分子内環化生成物 40 のシクロペンタ ジエンの1,5-シグマトロピー型の水素移動反応である。そ のため,アンモニア処理は必要がないと判断し，38をメタ ノール中加熱することで反応は完結した。そのため煩雑な後 処理操作をすることなく白色固体の AHX（3）が得られた. また，DICA（38）から ICA（2）への窒素の脱離と水素化 による変換反応は $\mathrm{Pd} / \mathrm{C}$ 触媒によって行われていたが，パラ ジウム金属が残留する問題があった。そこで，触媒を Rh/C に変更することで残留金属を $309 \mathrm{ppb}$ 以下とすることが可能 となった．さらに，Pdから Rhに変更することで反応の加速 が見られ，3の副生も抑えられた。これら一連の反応は結晶 化による精製が可能で一切のカラムクロマトグラフィーを必 要としなかったため 100 グラム以上のプロセス合成を可能に した。また，当初 3 から 4 への変換反応は高価なキサンチン オキシターゼによる酸化を実施していたが，静岡大学にて安 価に変換可能な微生物菌体（Burkholderia contaminans）を
天然より発見した。この酵素による酸化反応は，反応溶液を 濃縮した条件においても実施が可能であり, 現在スケール アップを検討中である.

\section{3. ダブルラベルFCsの合成}

静岡大学の詳細な研究の結果により FCsが多岐にわたる種 の植物の成長を促進することが明らかとなった，そこで，河 岸教授はFCsが元々植物に内生していると仮説を立てて詳細 な研究を行い, FCsが多くの植物に普遍的に内生しているこ とを証明した。このことは, FCsが新たな植物ホルモンであ る可能性を示唆している. 植物ホルモンとしての証明には, 生合成経路に関わる遺伝子のノックアウトにより起こる表現 型の変化の確認が必須となる。そのため, 生合成経路の確 定と代謝物の微量分析方法確立のため, イミダゾール環に二 つの ${ }^{13} \mathrm{C}$ 原子を導入したFCsの合成に着手した。また，その 際，高感度分析を実現するにあたり， ${ }^{13} \mathrm{C}$ 原子のソースとな る試薬には $1 \%$ の ${ }^{12} \mathrm{C}$ 原子が存在するため, LC-MSの精度に 対して完璧ではないと判断した。 そこで，二つの ${ }^{13} \mathrm{C}$ 原子を

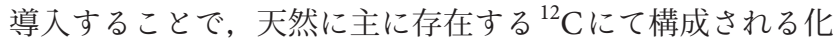
合物が標識体合成上では $0.01 \%$ 以下と抑えられる，スキーム

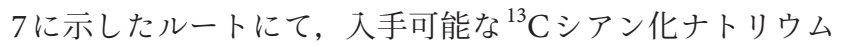
と ${ }^{13} \mathrm{C}$ オルド酸トリエチルを ${ }^{13} \mathrm{C}$ 炭素源としてイミダゾー

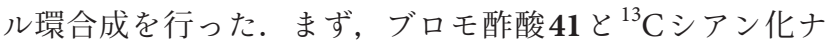
トリウムを反応させた後, 酸性条件下エチルエステルに変 換した。続いて， $\alpha$-シアノエステルに対してニトロソ中間 体を経由してオキシムを導入し，42 を得た。さらに，42の オキシムを水素添加反応によりアミンへと還元した後, アン モノリシスにより環化前駆体の $\alpha$-アミノニトリル43を合成

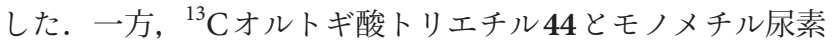
45 を酢酸中加熱すると得られる 46 に 43 を作用させるとイミ 
<smiles>CCOC(=O)C(N=C(C)C)=NO</smiles>

41

42

43<smiles>CNC(=O)N[14C]NC(=O)NNC(=O)NNC(=O)N[14CH3]</smiles>

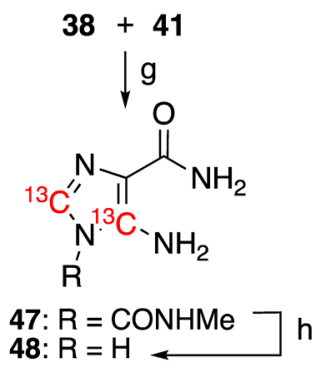

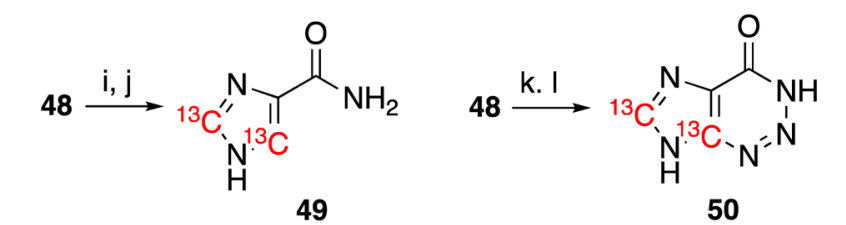

49

50

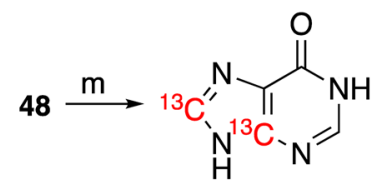

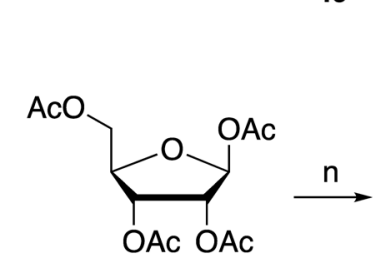

52

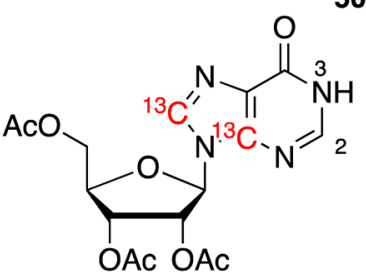

53

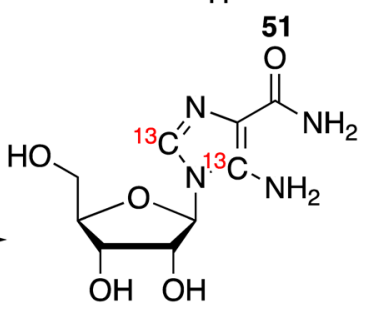

54

Conditions; (a) $\mathrm{Na}^{13} \mathrm{CN}, 1 \mathrm{M} \mathrm{NaOH}, 100{ }^{\circ} \mathrm{C}$; (b) $\mathrm{EtOH}, \mathrm{H}_{2} \mathrm{SO}_{4}$, reflux, $91 \%$ (2 steps); (c) $\mathrm{NaNO}_{2}, \mathrm{AcOH}$, $\mathrm{H}_{2} \mathrm{O}, 5{ }^{\circ} \mathrm{C}, 81 \%$; (d) $\mathrm{H}_{2}$, $\mathrm{Pd} / \mathrm{C}$, AcOEt, 86\%; (e) $\mathrm{NH}_{3}, \mathrm{MeOH} 10^{\circ} \mathrm{C}, 37 \%$; (f) $\mathrm{AcOH}, 100{ }^{\circ} \mathrm{C}, 74 \%$; (g) $\mathrm{AcOH}, \mathrm{MeOH}$; (h) Et $\mathrm{t}_{3} \mathrm{~N}, \mathrm{MeOH}, 80^{\circ} \mathrm{C}, 60 \%$ (2 steps) (i) $\mathrm{NaNO}_{2}$, aq. $\mathrm{HCl}, 0{ }^{\circ} \mathrm{C}$; ( j) $\mathrm{H}_{2}, \mathrm{Rh} / \mathrm{C}, \mathrm{MeOH}$, $61 \%$ (2 steps); (k) $\mathrm{NaNO}_{2}$, aq. $\mathrm{HCl}, 0{ }^{\circ} \mathrm{C}$; (l) $\mathrm{MeOH}, 60^{\circ} \mathrm{C}, 60 \%$ (2 steps); (m) $\mathrm{CH}(\mathrm{OEt})_{3}$, DMF, $130{ }^{\circ} \mathrm{C}$; (n) 51, BSA (bistrimethylsilylacetao, DCE, $70^{\circ} \mathrm{C}$; TMSOTf, $70^{\circ} \mathrm{C}$; (o) 1-chloro-2,4-dinitrobenzene, $\mathrm{K}_{2} \mathrm{CO}_{3}$, DMF , $60^{\circ} \mathrm{C}, 44 \%$ (3 steps); (p) ethylenediamine, $\mathrm{CH}_{3} \mathrm{CN}, 60^{\circ} \mathrm{C}, 52 \%$

$$
\text { スキーム 7. 二重 }{ }^{13} \mathrm{C} \text { 標識FCsの合成ルート. }
$$

ダゾール 47 が得られた. 続いて 47 にメタノール中 $\mathrm{Et}_{3} \mathrm{~N}$ を 作用させカルバモイル基の加溶媒分解を行い, ${ }^{13} \mathrm{C}$ ダブルラ ベルAICA（48）を合成した。その後，ジアゾ化反応による DICA 中間体を経由した ${ }^{13} \mathrm{C}_{2}$-ICA (49), ${ }^{13} \mathrm{C}_{2}$ - AHX (50) の変換は非同位体標識化合物の合成と同様の方法にて行っ た. ${ }^{11)}$

さらに, FCsが核酸前駆体のヒポキサンチンと類似構造を 有するため, 生合成前駆体のリボシル誘導体の合成に着手し た.しかし， ${ }^{13} \mathrm{C}_{2}$-ICA (49) ${ }^{13} \mathrm{C}_{2}$ - AHX（50）の直接的な リボシル化は困難を極めた。 ${ }^{12}$ そのため, ${ }^{13} \mathrm{C}_{2}$-AICA（48） にオルトギ酸トリエチルを作用させて, 一度 ${ }^{13} \mathrm{C}_{2}$-ヒポキサ ンチン（51）へと変換した。続くリボシル化は，51にN,Oビストリメチルシリルアセトアミド（BSA）を作用させてシ リルアミド中間体へとした後，52とTMSOTfを作用させる ことで円滑に進行し53が得られた。ささらに，53の3位窒素

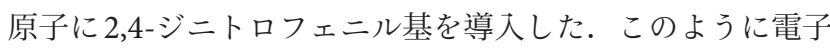
求引性の置換基を導入することで, 続くエチレンジアミン 処理での 2 位への攻撃が進行して，ジヒドロイミダゾールの 脱離を伴い54が得られた．非同位体標識化合物の合成に従 うと 54 から, ${ }^{13} \mathrm{C}_{2}$-ICA ${ }^{13} \mathrm{C}_{2}$ - $\mathrm{AHX}$ のリ゙シドへの変換は
容易に可能である. また， 54 から核酸のアデノシンへの変 換や49からアミノ酸のヒスチジンの合成も文献既知である. そのため, これらイミダゾール誘導体はダブルラベル化され た核酸やアミノ酸などの合成の有用な中間体と考えることが できる。

\section{おわりに}

以上，述べてきたように，当研究室にて開発したルートを 基盤にウシオケミックス社の協力を得てノビレチンとフェア リーケミカルズの 100 グラムスケールでの合成に成功した. 合成したノビレチンは試薬としての価格破壊を実現させると ともに, 多くの共同研究者への無償配布が可能となり, これ まで不可能であった動物実験も実現した。また, フェアリー 化合物では戋場での植物成長促進剤の可能性の試験を可能に して, 現在はバイオシュミラント剤として開発中である. 本 研究のノビレチン研究では新たな農林水産政策を推進する実 用技術開発事業の, フェアリー化合物の研究はイノベーショ ン創出基礎的研究推進事業・技術シーズ開発型研究の支援を 受けた。 


\section{引 用 文 献}

1) K. Tseng: J. Chem. Soc. 1003-1004 (1938).

2) A. Murakami, Y. Nakamura, K. Torikai, T. Tanaka, T. Koshiba, K. Koshimizu, S. Kuwahara, Y. Takahashi, K. Ogawa, M. Yano, H. Tokuda, H. Nishino, Y. Mikami, Y. Sashida, S. Kitanaka and H. Ohigashi: Cancer Res. 60, 5059-5066 (2000).

3) M. Al Rahim, A. Nakajima, D. Saigusa, N. Tetsu, Y. Maruyama, M. Shibuya, H. Yamakoshi, Y. Tomioka, Y. Iwabuchi, Y. Ohizumi and T. Yamakuni: Biochemistry 48, 7713-7727 (2009).

4) T. Furuta, M. Nakayama, H. Suzuki, H. Tajimi, M. Inai, H. Nukaya, T. Wakimoto and T. Kan: Org. Lett. 11, 2233-2236 (2009).

5a) A. R. Katritzky, N. Shobana, J. Pernak, A. S. Afridi and W.-Q. Fan: Tetrahedron 48, 7817-8152 (1992).

5b) A. R. Katritzky and A. Pastor: J. Org. Chem. 65, 3679-3682 (2000).

6) T. Asakawa, A. Hiza, M. Nakayama, M. Inai, D. Oyama, H. Koide, K. Shimizu, T. Wakimoto, N. Harada, H. Tsukada, N. Oku and T. Kan: Chem. Commun. (Camb.) 47, 2868-2870 (2011).

7a) 富士フイルム和光純薬株式会社：製品情報 天然物〈http://www. siyaku.com/uh/Shs.do?dspCode=W01CHDASB-00014490 >

7b）富士フイルム和光純薬株式会社：製品情報 合成品〈http://www. siyaku.com/uh/Shs.do?dspWkfcode=149-09341>

8) T. Horie, M. Masumura and F. S. Okumura: Bull. Chem. Soc. Jpn. 34, 1547-1580 (1961).

9) For review of fairy chemicals, see; (a) H. Kawagishi,: Proc. Jpn. Acad., Ser. B 95, 29-38 (2019). (b) H. Kawagishi: Biosci. Biotechnol. Biochem. 82, 752-758 (2018).

10) J.-H. Choi, T. Ohnishi, Y. Yamakawa, S. Takeda, S. Sekiguchi, W. Maruyama, K. Yamashita, T. Suzuki, A. Morita, T. Ikka, R. Motohashi, Y. Kiriiwa, H. Tobina, T. Asai, S. Tokuyama, H. Hirai, N. Yasuda, K. Noguchi, T. Asakawa, S. Sugiyama, T. Kan and H. Kawagishi: Angew. Chem. Int. Ed. 53, 1552-1555 (2014).

11) K. Ikeuchi, R. Fujii, S. Sugiyama, T. Asakawa, M. Inai, Y. Hamashima, J.-H. Choi, T. Suzuki, H. Kawagishi and T. Kan: Org. Biomol. Chem. 12, 3813-3815 (2014).

12) H. Ouchi, T. Asakawa, K. Ikeuchi, M. Inai, J.-H. Choi, H. Kawagishi and T. Kan: Tetrahedron Lett. 59, 3516-3518 (2018).

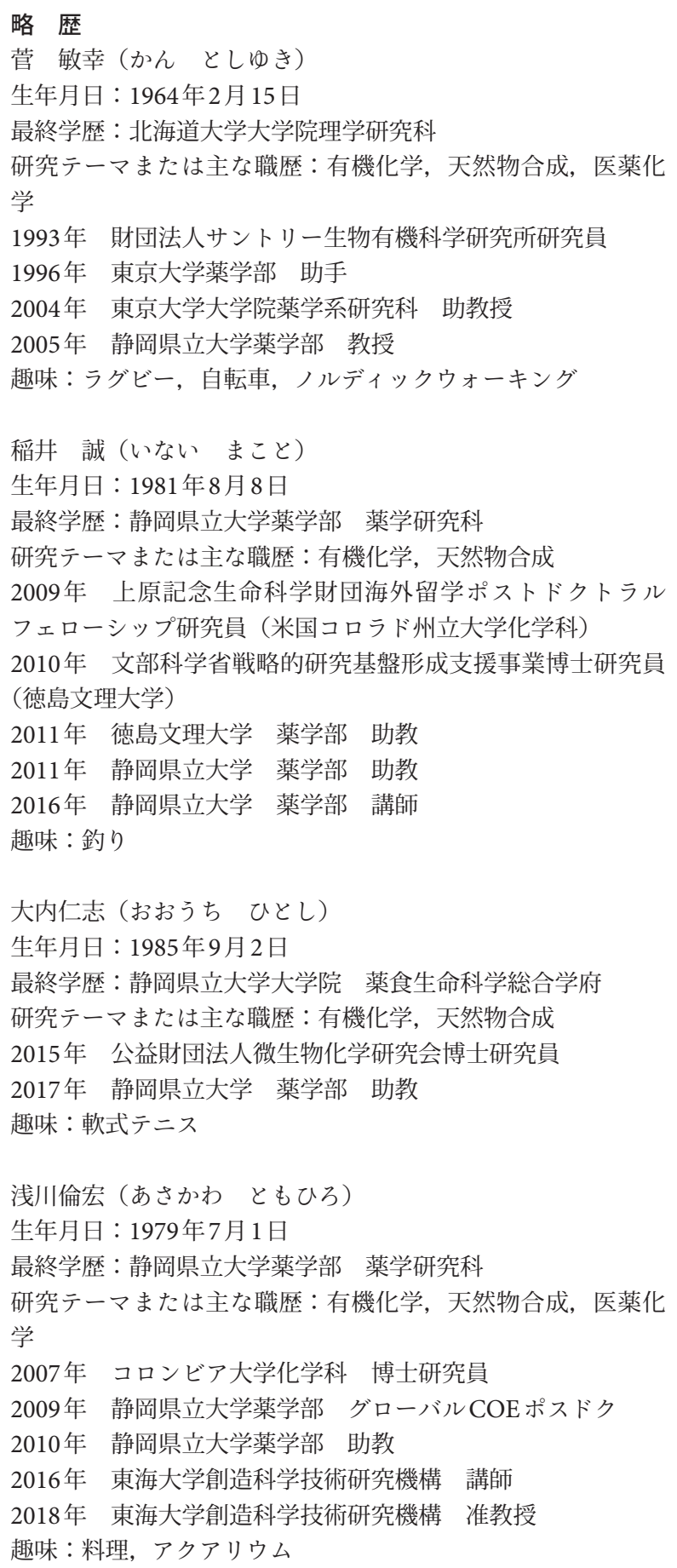

